\title{
Parents' role in adolescents' leisure time use: From goals to parenting practices
}

\author{
Annelore Van der Eecken*, Bram Spruyt ${ }^{* *}$, Lieve Bradt ${ }^{* * *}$
}

\begin{abstract}
Inspired by Ann Swidler's toolkit theory, this qualitative study aims to achieve a better understanding of social class differences in parenting practices and, in turn, in young people's leisure time use. To that end, 32 semi-structured face-to-face interviews with parents from middle- and working-class families were conducted in a small city in Belgium. An inductive thematic analysis revealed substantial social class differences with respect to three parenting practices: (1) setting an example, (2) resolving conflicts and (3) facilitating leisure activities. The interviews showed that these differences were mainly linked to social class differences in parents' resources: working-class parents more often lacked flexible time, financial resources, an extensive social network on which they could rely and the institutionally required attitudes, skills and experience to engage in the above-mentioned parenting practices. We conclude that young people's (continued) institutional leisure participation puts high requirements on parents and not all (workingclass) parents are able to live up to such requirements. In that way, contemporary leisure settings reproduce rather than mitigate inequality in the use of leisure time.
\end{abstract}

\section{Article History}

Received: 07 December 2019

Accepted: 29 January 2020

\section{Keywords}

Parenting practices;

Adolescents; Leisure

activities; Resources;

Social class differences

\section{Introduction}

Today, policymakers and researchers pay a lot of attention to young people's participation in adultsupervised, regular and rule-led activities that occur in an institutionalised setting (Bennett, Lutz and Jayaram, 2012). Such organised activities are believed to contribute to young people's skills and attitudes, and in that way, prepare them for their adult lives (European Commission, 2015; Muyters, 2014; Wyn and Woodman, 2006). However, young people's participation in organised activities differs according to socioeconomic status: working-class young people are often underrepresented (Bennett et al., 2012; Furlong and Cartmel, 2007). As these young people are believed to miss out on important learning opportunities, policymakers and researchers problematise their non-participation and try to increase their participation levels (Van de Walle, Coussée and Bouverne-De Bie, 2011). Based on the finding that parents play an important role in young people's leisure time use, policymakers and researchers approach parents as 'leisure providers' and 'facilitators', who are expected to make sure that their children's leisure time is wellspent, that is, in assumed beneficial organised leisure activities (Council of Europe, 2003; Fawcett, Garton and Dandy, 2009; Zeijl, 2001). Research demonstrates, however, that there are persistent social class differences in the role parents play in their children's leisure time use. Lareau (2003) and Vincent and Ball (2007) found that while middle-class parents actively encourage their children's involvement in organised leisure activities, working-class parents impose less structure on their children's activities and focus less heavily on such participation. For middle class parents, steering their children to a great variety of organized activities was a key component of the planned 'developmental trajectory' they designed for their

\footnotetext{
*OCMW Dilbeek, Belgium, email: annelore.vandereecken@dilbeek.be, ORCID: https://orcid.org/0000-0003-0830-2137

** Vrije Universiteit Brussel, Sociology Department, Brussels, Belgium, e-mail: bram.spruyt@vub.be, ORCID: https://orcid.org/0000-0003-0573-724X

${ }^{* * *}$ Ghent University, Faculty of Psychology and Educational Sciences, Department of Social Work and Social Pedagogy, Ghent, Belgium, e-mail:lieve.bradt@ugent.be, ORCID: https://orcid.org/0000-0003-4882-7675
} 
children.

Although it is not yet clear why social class differences in the parents' role and, in turn, in young people's leisure time use, come about in practice, researchers and policymakers plea for initiatives to inform, advise, convince and educate parents of these so-called non-participants (i.e. often working-class parents) about the educational benefits of organised leisure participation (Council of Europe, 2003). What is remarkable, though, is that we found in an earlier study that there are no large differences in the educational goals that parents from different social class backgrounds pursue for their children: our earlier work documented that when asked about the educational goals parents attached to their young people's leisure time, both middle- and working-class parents referred to the same goals to which leisure activities should contribute: teaching young people skills and societal values and norms, having social contexts, fostering independence and offering relaxation (see Van der Eecken, Spruyt and Bradt, 2019). This means that differences in young people's leisure time participation cannot be explained by differences in educational goals of working- and middle-class parents.

Given this lack of clarity, this study aims to gain a better understanding of social class differences in the role of parents and, in turn, in adolescents' leisure time spending using data from 32 interviews with a socio-economically diverse group of parents of adolescents (aged between 12 and 18 years old) in Flanders (the Dutch-speaking part of Belgium). The class perspective used in this paper is inspired by the work of Pierre Bourdieu $(1986,1993)$. According to Bourdieu, tastes, attitudes and behaviour vary with cultural (skills, knowledge, values, educational degrees and professional titles), social (resources accrued by virtue of possessing a network) and economic (material and financial resources) capital. The overall volume of capital can be seen as a continuum on which individuals occupy different positions (Bourdieu, 1986; Woodman and Wyn, 2015). In this paper, we are interested in parents who strongly differ in terms of their general volume of capital: middle- and working-class parents. Though we recognize that both middle- and to a lesser extent working-class parents cannot be considered as homogenous groups (and in fact vary in terms of their capital composition), in this study we aimed at identifying clear dimensions of stratification between working-class and middle-class parents. We, therefore, categorise parents into two groups. In the following section, we first go into the Toolkit theory of Swidler as our main theoretical framework.

\section{From Goals to Strategies of Action: Culture as a Toolkit}

This paper aims to advance our understanding of social class differences in the role parents play in adolescents' leisure time activities. In this section, we argue that a shift from a focus on people' goals to people's strategies of action might help us to get a better grip on these differences.

As already mentioned, previous research (Van der Eecken et al., 2019) suggests that social class differences in parents' role cannot be explained by social class differences in the goals that parents pursue through their children's leisure participation. This finding aligns with a more general observation that what people want contributes little towards explaining their effective behaviour (Swidler, 1986). Indeed, Ann Swidler was one of the first scholars to show that people may have similar aspirations while remaining profoundly different in the way they act. Her ideas criticised the traditional view of culture in which, for example, poor people were thought to hold low aspirations and to reject middle-class values and norms, and for these reasons did not seize opportunities to improve their situation. In contrast, Swidler (1986, p. 275 ) holds that poor and lower-class people share the goals and ideals of the middle class: "In repeated surveys, lower class youth say that they value education and intend to go to college, and their parents say they want them to go". Given the similarities, she concludes that values and aspirations are of little use in understanding differences in behaviour. In changing circumstances there is a continuity in the way of life, not because the ends people want to achieve remain stable but because of the persistence of their strategies of action:

If one asked a slum youth why he did not take steps to pursue a middle-class path to success (or indeed asked oneself why he did not pursue a different life direction) the answer might well be not 'I don't want that life' but instead 'Who, me?' One can hardly pursue success in a world where the accepted skills, style and informal know-how are unfamiliar. One does better to look for a line of action for which one already has the cultural equipment (Swidler, 1986, p. 275). 
Parents' role in adolescents' leisure time use: From goals...

Swidler's work has influenced scholars who approach culture as a toolkit of resources that people rely on for constructing strategies of action (see also Lamont and Small, 2008; Lizardo and Strand, 2010; Vaisey, 2010). These strategies do not refer to a conscious and fully thought out action plan that is directed towards certain predetermined goals, but rather to habitual ways of ordering action through time. From a more analytical point of view, then, the toolkit approach argues that people fail to take up chances to reverse their situation not so much because they remain committed to their 'cultural values' but because they have adopted strategies of action for which they already possess the resources. Thus, instead of strategies being developed on the basis of values or ends, actions and values are organised to benefit from the resources that are available to them. This is not because people despise the possible advantageous effects of new strategies of action but because the resources needed to develop them would demand strong retooling.

The toolkit approach enables us to understand the apparent inconsistencies between what people want and what people actually do. For instance, even though a mother may find it important that her children are signed up for an organised activity, she may give her children a freer rein in choosing their own hobbies. She may not want to waste her limited financial means on activities that turn out to be not interesting. Thus, as some people do not have the necessary resources (here: money), they are not likely to pursue certain courses of action. In other words, the toolkit theory shifts the attention from the goals people pursue and directs it to the resources that are available to them and which form the basis for their action. Informed by the preceding arguments, this study examines the parenting practices related to adolescents' use of leisure time and aims to better understand social class differences in these practices. Parenting practice is here used not in the conventional sense of goal-oriented parenting actions (Fletcher, Elder and Mekos, 2000), but rather to refer to the routine practices of parents in relation to their adolescents' use of leisure time.

\section{Method}

This study is based on 32 interviews with middle- and working-class parents living in Ninove, a medium-sized city in Flanders. Ninove has a population density of 526 inhabitants per $\mathrm{km}^{2}$ (Population Affairs Department Ninove, 2016). Choosing a medium-sized city has the advantage that people live in relatively close proximity to each other. In that way, we attempted to rule out differences in parenting practices attributable to local differences in accessibility and availability of the leisure facilities and programmes between the respondents. In addition, as this city is the first researcher's living environment, the researcher had prior knowledge (e.g. knowledge of the city's leisure facilities, meeting places and youth policy) that allowed her to ask more specific questions and to understand subtle remarks.

Ninove is an average Flemish municipality, which is like many other cities in Flanders, characterised by a diverse population in terms of income, migration status and family composition. Ninove scores average on income statistics. In 2013, the average income per tax return in euro was 31,521 , which is comparable to the average income per tax return in the Belfius medium-sized cities where it was 31,088 and slightly lower than in the Flemish region, where it was 32,275 (Agency Internal Governance and Research Department of the Flemish Government, 2016). Some statistics, however, indicate that some households live in adverse financial circumstances. In 2016, the number of persons with an (equivalent) minimum substance income in the context of the Right to Societal Integration per 1,000 inhabitants was 4.9 in Ninove (compared to 5.0 in the Belfius medium-sized cities and 5.4 in the Flemish region) and the number of persons with an increased allowance in the sickness insurance - in Belgium this allowance is only granted in case of high costs and proven low financial means - per 1,000 inhabitants was 147.7 in Ninove (compared to 143.0 in the Belfius medium-sized cities and 137.2 in the Flemish region) (Agency Internal Governance and Research Department of the Flemish Government, 2016). In 2015, the number of persons (18 years and older) that fell behind on financial loans per 1,000 inhabitants was 30.3 in Ninove (compared to 28 in the Belfius medium-sized cities and 26.4 in the Flemish region.

To summarise, although we do not claim that Ninove is a municipality with severe poverty and disadvantage, the statistics illustrate that there is a group that is suffering hardship (as in other Flemish 
municipalities).

\section{Recruitment of Participants and Data Collection}

In setting up the methodology, we followed the general ethical protocol of the Faculty of Psychology and Educational Sciences of Ghent University (https://www.ugent.be/pp/en/research/ec/overview.htm). As mentioned above, we aimed to involve both middle- and working-class parents in our study. As it is well-known that families from different socio-economic groups live in different districts of the city (Hamnett, 2001), parents were recruited from two predominantly working-class districts and two predominantly middle-class districts in the city centre of Ninove. Most respondents were randomly addressed on the street (20 parents of whom 13 were working-class), asked whether they had a child in the age group 12 to 18 years old and, if so, they were invited to take part in our study. We also recruited one working-class respondent through an advert in a local social media group, five middle-class parents via the local neighbourhood committees and four middle- and two working-class parents via snowball sampling. Parents were free to choose whether they did the interview alone or together with their partner. In general, the mother preferred to do the interview (alone), which is common in research on parents (see Wheeler, 2014).

After parents gave their written consent to participate in the study, semi-structured audio-recorded face-to-face interviews were conducted between September and December 2016. Respondents were informed that all information of the interview would remain confidential, that they did not have to answer questions they did not feel comfortable with, and that they even could end the interview without having to give a specific reason for this. The length of most interviews varied between one and two hours. As a starting point and to gain insight into adolescents' use of leisure time, parents were asked to provide an overview of how the adolescent spent his/her leisure in the week before the interview. For that purpose, parents relied on their personal definitions of 'leisure' and 'leisure time'.1 The interviews further focused on how young people's use of leisure time came about and the parents' role therein. Examples of specific questions included, but were not limited to: 'How did s/he get involved in a particular leisure activity?', 'Were there moments that s/he wanted to give up on an activity and how did that go?' and 'Are there activities that you prefer and how do you facilitate them?'

\section{Sample}

We interviewed 37 (step-)parents (i.e. biological parents and/or their partner). The interviewees consisted of 27 mothers and 10 fathers (five mothers and fathers were interviewed together) with at least one (step-)child 2 in the 12 to 18 years old age group. The families had between 1 and 6 children with ages ranging from 0 to 31 years. The mean age of the child in the 12 to 18 years old age group was 14.8 years. As middle-class parents may live in working-class districts and vice versa, parents were asked about their own and their partners' highest educational qualification as an 'individual check'. As argued before, we were primarily interested in parents who strongly differ in terms of their general volume of capital (Bourdieu, 1986). Education was used as a proxy for parents' volume of capital because (1) it provides a clear hierarchy (especially in Flanders where differences according to educational institutions are small, people's level of education is an excellent indicator of people's general volume of capital3) and (2) it applies to everyone (i.e. in contrast with occupational categories). When applicable, the educational level of both parents was taken into account because we assume that parents influence each other's ideas and behaviours (Schofield and Weaver, 2016). Families were categorised as 'middle-class' in our study if at least one parent had obtained a tertiary education degree and 'working-class' if none of the parents had done so. Sixteen families were categorised as working-class and 16 as middle-class families. If we look at our sample, the data

\footnotetext{
${ }^{1}$ Thereby, little social class differences were found: both middle- and working-class parents defined leisure activities as activities that the adolescents have chosen themselves, that aren't obligatory, that suit them, that interest them, that they enjoy, that develop them, that are useful and that relax them.

2 Stepchildren refer to the biological children of one's partner.

${ }^{3}$ Indeed, research indicates that people in Belgium with a bachelor's and master's degrees have seen their wages rise more sharply in recent years than employees without higher education (see: https://statbel.fgov.be/en/themes/work-training/wages-andlabourcost/overview-belgian-wages-and-salaries)
} 
Parents' role in adolescents' leisure time use: From goals...

confirmed that parents in families with different educational qualifications indeed differ in ways that are typically associated with the distinction between the middle- and working-class. After all, in higher educated families at least one of the parents had a job involving responsibility and accountability and/or requiring higher qualifications. For instance, occupations mentioned by respondents in higher educated families were manager, director, advisor, teacher, (higher) clerical employee, technician, driver, nurse and social worker. Parents in lower educated families, on the contrary, had jobs without these features: they mentioned labourer, cleaning lady, (routine) clerical worker and patient care assistant. Three working-class respondents were disabled 4 and four were housewives. There were eight single parent families (of whom four were working-class) and six stepfamilies (of whom four were working-class). No systematic class differences in family forms could be noticed. Five families had a migration background, 5 amongst whom four working-class families had a non-European background. In line with previous findings of Bennett et al. (2012) and Lareau (2003), we found social class differences in young people's leisure patterns: while children of middle-class parents participated extensively (and simultaneously) in different types of organised leisure activities (the average number of organised activities per adolescent was 1.63, based on 27 children of middle-class parents), children of working-class parents were more likely to spend their leisure time in an informal setting (the average number of organised activities per adolescent was 0.46, based on 24 children of working-class parents). Two examples serve to illustrate this observation: Lucas, a 14-year-old middle-class boy, participated in Scouts, athletics, hockey, music school and harmony and combined this with gaming, using the internet, reading books and meeting friends. Levi, a 13-year-old working-class boy, spent most of his time BMXing in the park and in the city, gaming, using social media, watching television and engaging in family activities. A schematic overview of the participants and their children's leisure activities can be found in the supplementary material (see Table 1 as an appendix).

\section{Analysis}

The interviews were transcribed. Though the interviews dealt with both parents' educational goals and parenting practices, for the purpose of this study we only focus on the data in relation to parenting practices in relation to young people's leisure time. Our analysis was theory-inspired in the sense that the toolkit theory directed our attention to the routine parenting practices in the domain of adolescents' leisure activity. Inductive thematic analysis was used to code the interview transcripts. The first author coded all passages referring to the routine parenting practices and found that these could be organised into three themes (Hsieh and Shannon, 2005). Additional coding identified the resources necessary for engaging in particular parenting practices. It was thus the researcher who looked for connections between parenting practices and resources. As explained in the introduction, the focus of our study was directed to comparisons between middle- and working-class parents (and not so much on within class variation). The discussion and revision of the results together with the second and third authors ensured the trustworthiness of our study (Lietz, Langer and Furman, 2006). To enable readers to adequately judge whether the findings of this study can be transferred to other settings, we have provided a clear and detailed description of the recruitment and characteristics of the participants, the interview procedure and the analytical process. The underrepresentation of fathers in our study is a limitation and must be kept in mind when interpreting and transferring the results.

In the following section, the results of the study are presented. In doing so, we focus on the parenting practices for which the largest social class differences could be noticed. In no way we claim that this is an exhaustive list of differences. One cannot determine in abstracto how large a difference must be in order to consider it as important. This decision always depends on the aim of the analysis. The aim of this analysis was gaining a better understanding of social class differences in parents' role and, in turn, in adolescents' use of leisure time. Therefore, we used the following criteria for including parenting practices in our study: there are class differences in (1) relying on a specific parenting practice and (2) the impact of that practice on young people's leisure time use (e.g. continued involvement versus dropping-out). Social class

\footnotetext{
${ }^{4}$ Disabled refers to being unable to work for more than one year.

${ }^{5}$ Families with a migration background are families where at least one of the parents is immigrated themselves or had parents who did.
} 
differences were more remarkable in parenting practices related to young people's organised leisure participation. As a result of particular characteristics of organised leisure activities (e.g. the presence of formal rules, the regular, consistent and timely attendance), young people's organised leisure participation, as we will show, placed heavier demands on parents, that is, required more resources which are unequally distributed across social class (Mahoney and Stattin, 2000).

To illustrate our findings we added quotations. All names used are pseudonyms. The letters ' $\mathrm{MC}$ ' and ' $W C^{\prime}$ after the pseudonyms in the citations refer respectively to middle- and working-class parents. The letters ' $\mathrm{I}$, ' $\mathrm{M}$ ' and ' $\mathrm{F}$ ' in the citations refer respectively to interviewer, mother and father.

\title{
Results
}

The largest social class differences were found in the following parenting practices: (1) setting an example, (2) resolving conflicts and (3) facilitating leisure activities. While setting an example was related to guiding young people into leisure activities, resolving conflicts was concerned with preventing young people from dropping out from activities. Facilitating young people's leisure activities was concerned with both aspects.

\section{Setting an Example}

Although it may sound obvious, setting an example is an important mechanism for guiding young people into particular leisure activities. As expected, the interviews showed that middle- and workingclass young people grew up in families where different kinds of leisure activities were undertaken. Through engagement in particular leisure activities (as a participant or as a professional/volunteer), parents awoke their children's interest in them. Such parenting actions were not always based on rational calculation.

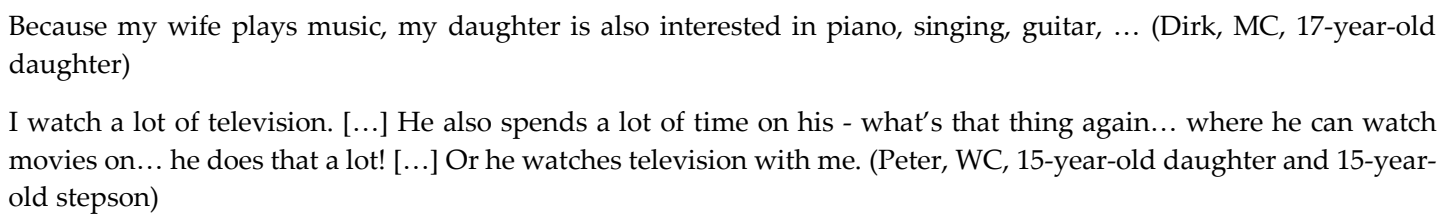

I watch a lot of television. [...] He also spends a lot of time on his - what's that thing again... where he can watch movies on... he does that a lot! [...] Or he watches television with me. (Peter, WC, 15-year-old daughter and 15-yearold stepson)

Especially middle-class parents also took their children with them to leisure activities such as cultural performances, exhibitions, concerts and sports, to stir up their interest:

\begin{abstract}
XXX never was attracted to museums and he certainly does not do that spontaneously. If we go on a trip, he reads in the foyer but in Germany, children could get in free and then I said: 'At the end, I'll come for you and then we go look at two or three paintings that I like to show you!' (Lea, MC, 18-year-old daughter and 14-year-old son)
\end{abstract}

Thus, if passing on leisure interests did not happen spontaneously, middle-class parents actively guided their children into certain activities. Because middle- and working-class parents differed in their leisure time patterns, simply 'being themselves' created and reproduced class differences in their children's leisure time patterns. While middle-class parents were engaged in a diversity of leisure activities outdoors, several working-class parents spent most of their leisure time engaging in 'passive activities' at home, such as watching television. These activities are cheap and require little physical effort. Such activities are dominantly seen as less valuable because they are sedentary and do not improve health, social skills and cognitive thinking. Working-class parents' less intensive leisure life (outdoors) was related to their more physically exhausting jobs and to their lack of flexible time. Indeed, middle-class parents had more time for leisure activities outdoors primarily because of flexible working arrangements: they were able to telework, start and stop earlier and alternate shorter with longer workdays, which improved their ability to schedule their outdoor (family) leisure activities. Working-class parents, however, generally had fixed working hours:

\footnotetext{
If you're working full time, you don't have an excessive amount of free time. [...] Ever since August, I am thinking: 'Hmm, what if I were to do sports one evening a week? [...] [But] I don't even have any time for that. [...] How do they [other parents] do sport in the week? I don't get it. (Alice, WC, 16-year-old daughter)
}

Moreover, several working-class parents declared that they were too tired to take part in outdoor 
Parents' role in adolescents' leisure time use: From goals...

leisure activities. They perceived their leisure time as a time they required to rest, recharge their batteries and to sit around with the family:

Watching television, going shopping once... but real real [activities]... No, we don't have any of that. We just don't get around to it. F: If I come home from work, I'm not in the mood to do anything anymore. (Mira and Ben, WC, 13year-old daughter)

Middle- and working-class parents further differed in the extent to which they were able to let their children experiment with a broad range of leisure activities. Common to many young people is that they want to experiment and try out different kinds of leisure activity before they find one that fits their interests and talents. In this context, middle-class parents' financial resources enabled them to give their children more opportunities to get a taste of different activities. They could better afford the cost of an activity that their children ultimately quit doing and in many cases they also had the financial means to present those activities repeatedly (as a deliberate attempt to get their children to like the activity). In contrast, workingclass parents were less inclined to introduce their children to (costly) outdoor leisure activities. They reasoned that if the adolescents did not enjoy them, they would have paid tickets for events, membership dues, leisure materials, etc. for nothing. They preferred to let their children follow their own leisure preferences to ensure that they 'stuck with' the activity:

She may do anything she wants but it isn't acceptable that she chooses a sport and that you're starting to make arrangements and that she says a month later: 'I don't like it!' Sorry but I also need my money! [...] My two other children did that. They followed dancing lessons in the sports hall until I had paid for those $\mathrm{t}$-shirts and stuff. Then they said: 'Mom, I don't like it anymore!' Then I said: 'God damn it!' (Karen, WC, 14-year-old daughter)

Not only their financial means but also their familiarity with (institutional) leisure activities outdoors enabled middle-class parents to present their children with a greater diversity of activities. Working-class parents had less experience with such activities (for young people), which was related to their own life history: they were not engaged in such activities as a child.

I never have played [organised] sports [as a child]. (An, WC, 18-year-old son)

Interestingly, the (working-class) parents' limited resources and experienced barriers (e.g. being tired after work) could be 'circumvented' by leisure clubs' attempts to recruit young people via the school:

They came to her school in September to recruit new members and she immediately wanted to start with it [the youth organisation]. She brought a folder home, which she showed to her brother and sister. All three then started. And they really like it so... (Elisa, WC, 14- and 12-year-old daughters)

All the quotes given so far clearly illustrate that leisure interests are created by parents as much as they are discovered by children. For instance, visiting museums was not an activity that Lea's son would do spontaneously. Young people's leisure interests are not 'innate' but (at least partly) the result of an everyday family modelling process (Bourdieu, 1993; De Graaf, De Graaf and Kraaykamp, 2000; Mullan, 2010). Those informal learning processes are not available to all: working-class parents generally lack resources (e.g. flexible time, money and experience) for and experience barriers (e.g. being exhausted at the end of a workday) to transmitting societally valued leisure interests to their children.

\section{Resolving Conflicts}

Parenting practices were not only concerned with getting young people involved in particular leisure activities, but also with preventing young people from dropping out from activities. Most (young) people reach a certain point where they want to quit an activity (Allison, Adlaf, Dwyer, Lysy and Irving, 2007; Furlong and Cartmel, 2007). On such occasions, especially middle-class parents then intervened (at an early stage) to prevent their children from giving up the activity. They felt (1) a sense of urgency, (2) a responsibility for finding a solution for issues and problems in the leisure setting, and (3) entitled (collectively) to call to account trainers/leaders/youth workers:

Letting a child of fourteen years old play [only] 2 minutes in the football game... that is actually a punishment! [...] XXX went through that once. [...] I said to the coach that I didn't like that. [Thereafter, it didn't happen anymore.] (Karel, MC, 17-year-old daughter and 15-year-old son)

We just undertook action with the parents. We called all parents after the 'transition weekend'. We grouped our 
thoughts - about the things that happened - and then we struck up a conversation with the leaders. [...] There were two things that weren't right at all for us. [...] Humiliation or pain, psychological pressure. [...] And also, the drinking of alcohol. They are old enough but they were even forced to drink alcohol. [...] We then asked the leaders: 'Can we come by to talk to you?' and then they said: 'Yes, after a meeting on Sunday, you are certainly welcome!' [...] They were going to discuss it with the group leaders but I still haven't heard from them. I also don't know if we will receive any feedback. But they make house visits, you can indicate that when signing them up. Then they give information about their operations for the year and then we definitely can talk about that once. (Lea, MC, 18-year-old daughter and 14-year-old son)

Working-class parents were more hesitant about approaching youth workers6:

I'm not a person that would immediately say: 'Yes and my child that and my child that...'. They have to figure it out themselves and do it on their own. Until a boundary is crossed where I say: 'Now I have to take action!' Or if something happens, then I will say my opinion. But otherwise I think: 'Yeah, they have to handle it themselves!' (Alice, WC, 16-year-old daughter)

This quote demonstrates that 'once a line was crossed', working-class parents also intervened. However, at this later stage, problems had already worsened to an extent that a solution was no longer possible with drop-out as a result:

He had to sit on the bench because he hadn't got enough ball technique and then I was thinking: 'I'm not paying to just sit on the bench, I'm not investing my time to always watch to a bench!' And finally, I asked him [the coach] about that and he said: 'Yes but he isn't good enough and I want to demote him to a lower group'. But he didn't want to do that. I said: 'Look, he doesn't want to do that, then I quit with it and he doesn't come anymore!' (Sien, WC, 13-yearold son)

The interviews made clear that resolving problems was facilitated by intervening rapidly and frequently in young people's leisure activity and mobilising other parents to respond collectively to incidents. A rapid intervention ensured that problems did not reach such proportions that they become insoluble. Especially middle-class parents were proactive in seeing that their children's needs were met; they felt entitled to demand more from leisure organisations. Working-class parents waited longer - until a line was crossed - to take action because they were more likely to see youth workers as experts that should not be questioned. Moreover, several working-class parents had not (completely) mastered the Dutch language, which operated as a barrier to opening up a dialogue. Further, addressing problems in a group put more pressure on youth workers to find a solution. Middle-class parents were - due to their extended parental networks (see below) - able to react collectively when confronted with problems. Working-class parents, however, often responded to problems individually: only the parent and youth worker were involved.

However, in this context we also found examples of youth workers who managed to resolve problems by breaking down barriers for (working-class) parents. For example, by proactively addressing parents in an effort to resolve prevailing problems, youth workers ensured that problems or issues did not grow and remain soluble:

Here they [the leaders] are very good, really! Attentively, attentive to differences. They pose questions... I was positively amazed about the fact that they talked to me about it [her daughter's language disorder] on the phone and I went down there... like an appointment... [...] They will make the necessary adjustments. For example, XXX will not have to recite the law of the Scouts. (Rosalie, WC, 13-year-old daughter)

Youth workers who guided the same group of children for years could anticipate difficulties without any need on the part of the parents to intervene repeatedly:

XXX has a lack of empathy and she has some difficulties with [accepting] authority. That has always been a problem but I have discussed that with the coach and in the meantime, he already knows how she is because she has had the same coach for years. He kept his team each year. (Ines, WC, 18-year-old son and 14-year-old daughter)

To conclude, although middle- and working-class parents were confronted with similar issues/problems, especially middle-class parents succeeded in resolving them (and assuring continued leisure participation) and in making leisure clubs work to their advantage.

${ }^{6}$ Youth workers here refers to the volunteers and people professionally qualified in a range of different types of work with young people (e.g. youth organisation, sports and music lessons). 


\section{Facilitating Leisure Activities}

Facilitating leisure activities was related to both guiding young people into, and preventing them from giving up on, particular leisure activities. Parents paid membership dues, provided leisure materials (e.g. books, sports equipment, skateboard and BMX), brought their children to their activities by car, gave permission to undertake informal activities outdoors (e.g. playing football, skating and meeting peers), accommodated family life to meet their children's leisure schedules, washed their sports equipment and 'trained' their children at home.

Although facilitating young people's leisure activities was at times difficult for all parents, the crucial difference was that middle-class parents' flexible working arrangements, financial means and social network offered them many more opportunities to cope with challenging situations. Indeed, the data showed ample examples of how small advantages accumulated over time into larger benefits and in this way created and reinforced class differentials. Many leisure organisations (and certainly those that are youth-led), for example, occasionally make late changes and/or communicate at the last minute about what is going to happen. Middle-class parents' financial means enabled them to manage these last-minute arrangements more easily. After all, money not only provides for paying membership dues and buying clothes or other leisure attributes but also for having (a) car(s). While middle-class parents generally had two cars, several working-class parents indicated that they could not afford a car. Not having a car made it difficult to be flexible in anticipating changes in leisure schedules:

If they said: 'We meet up there at that hour' and then it was at another time and another place, then I thought: 'Yeah but...', you know? All very last minute... You always must ensure that you could jump, as a manner of speaking. (Alice, WC, 16-year-old daughter)

Another example is that all parents were sometimes pressed for time because of work and/or family demands, which limited their options for facilitating their children's leisure activities. Feeling short on time was, however, even worse for employed working-class parents because they did not have flexible working arrangements:

Sometimes it [driving her children] is difficult, because I work in shifts. If I have to work in the morning, then there is no problem but if I have to work in the evening, then it is difficult. [...] I also work every other weekend. (Ines, WC, 18-year-old son and 14-year-old daughter)

Being a single parent also reinforced parents' time problem.

The problem is that the activities [of my children] overlap. If you have a partner, then it is easier. One goes to that activity and the other to another activity. Then you can arrange it. But I'm single. (Eva, MC, 15- and 13-year-old son)

Middle-class parents not only had more flexible working arrangements, they also had sufficient financial resources and a strong, extended and available social network to compensate for their lack of time. For example, in one case their financial means enabled them to hire a nanny to drive their children to and from their activities:

On Monday and Wednesday, it is training and on Saturday match. On Saturday, my husband does it and on Monday, Tuesday and Thursday, we have a nanny for the children. She comes here after school and she brings XXX to the football training. (Katrien, MC, 12-year-old daughter)

The middle-class parents made carpooling arrangements with co-participants' parents, neighbours or family members. Working-class parents did not have close contacts with residents in their district and faced difficulties in building up relationships with other parents at the leisure setting. They rather relied on kinship networks which were, however, generally less resourceful (e.g. not having flexible time and an available car). Some family members of parents with a migration background were also living far away.

I have always lived in this district but things here have become much worse... I: In what sense? M: Scum... Boorish [people]... A lot of immigrants came [to reside in this district]... (Mira, WC, 13-year-old daughter)

There was already an introduction, to let us know how it is going there [the youth organisation]. [...] I'm not in contact with them [the co-participants' parents]. [...] You see that they aren't that open. You see that they aren't such social people. I have the quick tendency to talk to everyone. If I am at the butcher and a stranger is standing next to me, I can say: 'What are you going to eat today?' I would dare that! But there it wasn't like that... (Elisa, WC, 14- and 12year-old daughters) 
This last quotation illustrates that institutional leisure contexts demanded a certain 'code of behaviour' that was less familiar to working-class parents. In addition, middle- and working-class parents often lack a shared frame of reference (e.g. different working conditions and leisure activities), which hindered communication. On top of that, several working-class parents (with migration background) spoke another language, which may have served as an additional barrier.

When working-class parents did establish relationships with co-participants' parents, the relationships were rather weak and weak ties were less likely to bring advantages such as carpooling arrangements. Especially middle-class parents forged strong ties: they undertook activities together, independent of the young people's leisure activities, often stimulated by their children's involvement in the same activity for several years and/or their children's participation in the same range of activities. Working-class parents' encounters with other parents were generally limited to those at the leisure venue:

We meet each other also outside the ice hockey [setting], not everyone, but two couples. Because of [the children's] ice hockey [involvement], we became friends. We even go on ski trips with them. (Charlotte, MC, 15-year-old son)

The parents of XXX [daughters' friend] have a tearoom... sometimes we go there... [but] it's not like we sit together. (Sarah, WC, 18-year-old daughter)

Middle-class parents in our study thus benefitted from more extensive toolboxes, which allowed them to build strong ties with other parents who also had more flexible working hours, larger social networks, etc. In this way, the homophily of social networks clearly further reinforced already existing class differentials in parental support for children's leisure time consumption.

A last example is that, although all parents had some difficulties with giving their children more autonomy as they got older, facilitating (cf. giving permission for) young people's informal leisure activities outdoors (with friends) was less evident for working-class parents because their children were more 'at risk' of putting up with 'wrong' peers they met in their immediate living environment:

In the park, there is a lot of 'mixture'. It is true that there are youngsters that play basketball or football or that ride on BMX bikes but there are also people using drugs. (Aida, WC, 12-year-old son)

Also in the school of XXX, there are youngsters using drugs and who got into trouble with the police. (Malika, WC, 18- and 13-year-old sons, 16-year-old daughter)

Thus, the working-class families involved in our study were not only constrained by their 'individual tools' but also by their living environment (neighbourhood and school).

In sum, although all parents struggled with facilitating their children's leisure activities, middleclass parents' larger, resourceful and nearby social network, flexible working arrangements, financial means and immediate living environment enabled them to overcome their difficulties more easily. Thereby, relatively small benefits accumulated into greater benefits. No matter how persistent and challenging, this accumulation of advantage for middle-class parents (and relative disadvantage for working-class parents) is, however, not inexorably determined. Indeed, a crucial observation was that in some cases (working-class) parents' lack of flexible time, an available car and a (strong) social network to rely on could be bypassed by carpooling systems organised by clubs, as well as other initiatives such as hiring buses:

They could ride with the football trainers and with the other parents. (Gertie, WC, 18- and 13-year-old sons and 12year-old stepson)

\section{Conclusion and Discussion}

This study aimed to advance our understanding of social class differences in the parents' role and, in turn, in young people's use of leisure time. Based on 32 interviews with a socio-economically diverse group of parents, substantial social class differences were found with respect to three parenting practices: (1) setting an example, (2) resolving conflicts and (3) facilitating leisure activities. These differences were systematically related to social class differences in resources: although middle- and working-class parents faced similar difficulties when it came to young people's use of leisure time (e.g. last-minute changes in organisations and young people's changing interests), middle-class parents' flexible time, financial means, 
Parents' role in adolescents' leisure time use: From goals...

extensive social network, institutionally required attitudes, skills and experiences and immediate living environment enabled them to overcome such difficulties more easily and engage smoothly in the aforementioned parenting practices. Although, it often came down to small, subtle (though persistent) things, the sum of small things led to big consequences (see also Currid-Halkett, 2017). Overall, it confronted working-class parents with more difficulties in shaping their children's spending of leisure time.

Our findings are in line with previous studies on social class and parenting. Similar to previous studies on parental involvement in the school context, we found that working-class parents felt less entitled to question the approach of professionals (De Graaf et al., 2000; Lareau, 2003). In their study on parental cultural capital and educational attainment, De Graaf et al. (2000) noted that middle-class parents feel more confident to intervene in (school or leisure) institutions because they are 'insiders' in the (school or leisure) field (i.e. parents participate (d) themselves in higher education and institutional leisure). Related to this, Horvat, Weininger and Lareau (2003) drew attention to the different personal network composition of middle- and working-class parents: in contrast to middle-class parents, who included parents of peers and professionals in their network, working-class parents mainly relied on support from relatives and neighbours. Parents of peers and professionals provide middle-class parents with resources which they can use to overcome difficulties. For instance, middle-class parents can call upon other parents to collectively respond to problems in school institutions (Horvat et al., 2003). Largely similar results were found in this study. An exception is that only a minority of the working-class parents referred to neighbour support. Time and context may explain these different findings. The study of Horvat et al. (2003) is based on data collected in 1989-1990 in the (ethnically) segregated USA. There was a large inflow of migration over the last years and ethnic segregation is less pronounced in Belgium. Not surprisingly then, we observed that the working-class parents in our study lived in increasingly ethnically mixed districts with limited interactions among neighbours. Our findings also somewhat deviate from those of Horvat et al. (2003) in the sense that we found that the support working-class parents receive from relatives had rather limited compensatory value. The fact that we included several working-class parents (with migration background) whose family members did not live nearby (e.g. they lived in the capital of Belgium or in another country) may at least partly explain these differences. However, the family was definitely a major source of emotional support for parents and especially working-class parents. Because of working-class children's less organised use of leisure time, working-class families had more room for time with family members (e.g. calling to, skyping with and/or visiting relatives).

The 'culture as toolkit' framework (Swidler, 1986) enables us to understand the paradoxical observation made in the literature that even though working-class parents value (institutional) leisure activities, they - at least at first glance - less actively encourage their children's participation in them. Our interviews showed that young people's continued (institutional) leisure participation placed heavy demands on parents and not all parents, especially not working-class parents, were able to live up to such requirements. Institutional leisure settings are predominantly organised around middle-class standards of good parenting whereby parents are seen as 'leisure providers' and 'facilitators' (Zeijl, 2001; Zinnecker, 1995). For example, parents are (implicitly) expected to make their children aware of the wide array of interesting (i.e. educationally important) activities available, to make the first approach to the youth workers should problems or issues arise, to drive young people to football games, etc. As a result, leisure initiatives are not always tailored to the living conditions of working-class families. Being aware of that is crucial to our understanding of inequality because it enables us to see how leisure organisations unwittingly contribute to inequality in the use of young people's leisure time.

What do these findings imply for future leisure time policymaking and practice? The current focus of policymakers on changing parents' presumed unawareness of the importance of their children's participation in (organised) leisure (see e.g. Council of Europe, 2003; Geudens, Costanzo, Hofmann, Amorim and Pavlovova, 2013) will not change social class differences in leisure time use patterns. As our findings show, young people's non-participation in institutional leisure activities stemmed not so much from a lack of interest from parents as from the availability of resources that enabled them to engage in 
particular institutionally valued parenting practices. Reversing inequality in leisure participation demands that leisure institutions critically reflect on how their way of working might hinder or facilitate vulnerable young people (and their parents) to take part in particular activities. In other words, it demands that leisure settings no longer start from middle-class conceptions of the parents' role in young people's use of leisure time (institutionally driven) but from families' concrete living conditions (lifeworld-oriented): what is happening in concrete situations and how can we tailor our way of working to the practices and living circumstances of these families? Our study shows that a number of relatively small adjustments can already have a major impact. For example, our findings showed that there were leisure clubs that used the school as a recruiting station, facilitated carpooling by connecting parents seeking respectively passengers and drivers, hired buses for young people's movement to games or performances, took the first step to approach parents if problems showed up, ensured continuity in youth workers, etc. Such relatively small things often had big consequences in the sense that they appeared to contribute to maintaining young people's participation in leisure activities. Our findings show that this kind of pedagogical engagement of these clubs can be important in circumventing parents' constrained resources.

In view of the finding that the 'small problems' experienced by families were relatively easy for youth workers to overcome, youth workers must reflect on the actions that they can undertake to reverse exclusionary processes (e.g. selective dropping out) and on what they can do to take the parenting practices and living conditions of all families into greater account. This suggests that instead of being occupied with organising young people's leisure time and guiding young people into organised leisure activities, youth policymakers should be more concerned with supporting young people in their (family) context (Coussée, 2006).

To get a complete picture of the strategies youth workers (can) use to circumvent exclusionary mechanisms within their organisation, further qualitative research with youth workers from diverse leisure contexts (football clubs, music school, youth organisations, etc.) is needed. Furthermore, longitudinal data is needed to establish unequivocally whether and how the identified strategies of parents and youth workers influence young people's leisure participation.

\section{Declarations}

Acknowledgements: Not applicable.

Authors' contributions: AVdE, BS and LB contributed to the design of the research, the analysis of the results and to the writing of the manuscript. AVdE carried out the data collection and initial data analysis.

Competing interests: The authors declare that they have no competing interests.

Funding: This research was part of the Youth Research Platform, which is funded by the Flemish Government, Department of Culture, Youth and Media. The Flemish government had no role in the design of the study, nor in the data collection and interpretation.

\section{References}

Agency Internal Governance \& Research Department of the Flemish Government (2016). Municipal profile Ninove. Brussels: Agency Internal Governance and Research Department of the Flemish Government.

Allison, K. R., Adlaf, E. M., Dwyer, J. J. M., Lysy, D. C., \& Irving, H. M. (2007). The decline in physical activity among adolescent students: A cross-national comparison. Canadian Journal of Public Health, 98(2), 97-100.

Bennett, P. R., Lutz, A. C., \& Jayaram, L. (2012). Beyond the schoolyard: The role of parenting logics, financial resources and social institutions in the social class gap in structured activity participation. Sociology of Education, 85(2), 131-157.

Bourdieu, P. (1986). Forms of capital. In J. G. Richardson (Ed.), Handbook of theory and research for the Sociology of Education (pp. 241258). New York: Greenwoord Press.

Bourdieu, P. (1993). The field of cultural production. UK: Polity Press.

Council of Europe. (2003). Recommendation Rec (2003) 6 of the Committee of Ministers to member states on improving physical education and sport for children and young people in all European countries. Brussels: Council of Europe.

Coussée, F. (2006). De pedagogiek van het jeugdwerk. Gent: Academia Press.

Currid-Halkett, E. (2017). The sum of small things. A theory of the aspirational class. Oxford: Princeton University Press. 
Parents' role in adolescents' leisure time use: From goals...

De Graaf, N. D., De Graaf, P. M., \& Kraaykamp, G. (2000). Parental cultural capital and educational attainment in the Netherlands: A refinement of the cultural capital perspective. Sociology of Education, 73(2), 92-111.

European Commission (2015). The contribution of youth work to address the challenges young people are facing, in particular the transition from education to employment. Results of the expert group set up under the European Union Work Plan for Youth for 2014-2015. Brussels: European Commission.

Fawcett, L. M., Garton, A. F., \& Dandy, J. (2009). Role of motivation, self-efficacy and parent support in adolescent structured leisure activity participation. Australian Journal of Psychology, 61(3), 175-182.

Fletcher, A. C., Elder, G. H., \& Mekos, D. (2000). Parental influences on adolescent involvement in community activities. Journal of Research on Adolescence, 10(1), 29-48.

Furlong, A., \& Cartmel, F. (2007). Young people and social change. New Perspectives. England: Open University Press.

Geudens, T., Costanzo, S. Hofmann, P., Amorim, L., \& Pavlovova, L. (2013). T-KIT. International voluntary service. Strasbourg: Council of Europe Publishing.

Hamnett, C. (2001). Social segregation and social polarization. In R. Paddison (Ed.), Handbook of urban studies (pp. 162-176). London: Sage Publications.

Horvat, E. M., Weininger E. B., \& Lareau, A. (2003). From social ties to social capital: Class differences in the relations between schools and parent Networks. American Educational Research Journal, 40(2), 319-351.

Hsieh, H.-F., \& Shannon, S. E. (2005). Three approaches to qualitative content analysis. Qualitative Health Research, 15(9), 1277-1288.

Lamont, M., \& Small, M. L. (2008). How culture matters: Enriching our understanding of poverty. In D. Harris \& A. C. Lin (Eds.), The colors of poverty: Why racial and ethnic disparities persist (pp. 76-102). New York: Russell Sage Foundation.

Lareau, A. (2003). Unequal childhoods: Class, race and family life. London: University of California Press.

Lietz, C. A., Langer, C. L., \& Furman, R. (2006). Establishing trustworthiness in qualitative research in social work. Implications from a study regarding spirituality. Qualitative Social Work, 5(4), 441-458.

Lizardo, O., \& Strand, M. (2010). Skills, toolkits, contexts and institutions: Clarifying the relationship between different approaches to cognition in cultural sociology. Poetics, 38(2), 205-228.

Mahoney, J., \& Stattin, H. (2000). Leisure activities and adolescent antisocial behavior: The role of structure and social context. Journal of Adolescence, 23(2), 113-127.

Mullan, K. (2010). Families that read: A time-diary analysis of young people's and parents reading. Journal of Research in Reading, 33(4), $414-430$.

Muyters, P. (2014). Policy note Sport 2014-2019. Submitted by Philippe Muyters, Flemish Minister of Work, Economy, Innovation and Sport. Brussels: Flemish government.

Population Affairs Department Ninove (2016). Population according to residence, nationality, age. Ninove: Population Affairs Department Ninove.

Schofield, T., \& Weaver, J. (2016). Democratic parenting beliefs and observed parental sensitivity: Reciprocal influences between coparents. Journal of Family Psychology, 30(4), 509-515.

Swidler, A. (1986). Culture in action: Symbols and strategies. American Sociological Review, 51(2), 273-286.

Vaisey, S. (2010). What people want: Rethinking poverty, culture and educational attainment. The Annals of American Academy of Political and Social Science, 629(1), 75-101.

Van der Eecken, A., Spruyt, B., \& Bradt, L. (2019). Giving young people a well-rounded education: a study of the educational goals parents attach to the leisure activities of their children. Leisure Studies, 38(2), 218-231.

Van de Walle, T., Coussée, F., \& Bouverne-De Bie, M. (2011). Social exclusion and youth work - from the surface to the depths of an educational practice. Journal of Youth Studies, 14(2), 219-231.

Vincent, C., \& Ball, S. J. (2007). 'Making up' the middle-class child: Families, activities and class dispositions. Sociology, 41(6), 10611077.

Wheeler, S. (2014). Organised activities, educational activities and family activities: How do they feature in the middle-class family's weekend? Leisure Studies, 33(2), 215-232.

Woodman, D., \& Wyn, J. (2015). Class, gender and generation matter: Using the concept of social generation to study inequality and social change. Journal of Youth Studies, 18(1), 1402-1410.

Wyn, J., \& Woodman, D. (2006). Generation, youth and social change in Australia. Journal of Youth Studies, 9(5), 495-514.

Zeijl, E. (2001). Young adolescents' leisure. A cross-cultural and cross-sectional study of Dutch and German 10-15 year olds. Opladen: Leske/Budrich. 
Annelore VAN DER EECKEN, Bram SPRUYT \& Lieve BRADT

Zinnecker, J. (1995). The cultural modernisation of childhood. In L. Chisholm, P. Büchner, H.-H. Krüger \& M. Du Bois-Reymond (Eds.), Growing up in Europe. Contemporary horizons in childhood and youth studies (pp. 85-94). Berlin: Walter de Gruyter. 


\section{APPENDIX}

Table I

Overview of the Participants

\begin{tabular}{|c|c|c|c|c|c|c|c|c|c|c|}
\hline $\begin{array}{l}\text { Inter } \\
\text { view }\end{array}$ & $\begin{array}{l}\text { Pseudo- } \\
\text { nyms }\end{array}$ & $\begin{array}{c}\text { Parents' } \\
\text { gender }\end{array}$ & $\begin{array}{l}\text { Adolescents } \\
\text { ' gender } \\
\text { (and age) }{ }^{7}\end{array}$ & $\begin{array}{l}\text { Number } \\
\text { of } \\
\text { children } \\
\text { in the } \\
\text { family }^{8}\end{array}$ & $\begin{array}{l}\text { Family } \\
\text { composi } \\
\text { tion }\end{array}$ & $\begin{array}{c}\text { Families' } \\
\text { migration } \\
\text { background } \\
9\end{array}$ & $\begin{array}{c}\text { Parents' } \\
\text { occupation }\end{array}$ & $\begin{array}{l}\text { Families' }^{\prime} \\
\text { education } \\
\text { al level }^{10}\end{array}$ & $\begin{array}{l}\text { Assigned } \\
\text { social } \\
\text { class } \\
\text { position }\end{array}$ & Adolescents' leisure activities $^{12}$ \\
\hline \multirow[t]{2}{*}{ I1 } & Sofie & Mother & Girl (16) & 2 & $\begin{array}{l}\text { Two- } \\
\text { parent } \\
\text { family }\end{array}$ & $\begin{array}{c}\text { No } \\
\text { migration } \\
\text { background }\end{array}$ & $\begin{array}{c}\text { Social } \\
\text { assistant }\end{array}$ & High & $\begin{array}{l}\text { Middle } \\
\text { class }\end{array}$ & $\begin{array}{l}\text { Ballet }(*) \text {, youth organisation }(*) \text {, fitness, going out, going to a pub, } \\
\text { using social media, surfing the internet, watching series, meeting up } \\
\text { with boyfriend, reading books, family activities (e.g. shopping and } \\
\text { going to a restaurant). }\end{array}$ \\
\hline & & & Girl (14) & & & & & & & $\begin{array}{l}\text { Ballet }(*) \text {, youth organisation }(*) \text {, using social media, watching series, } \\
\text { watching (creative) YouTube videos, baking, family activities (e.g. } \\
\text { shopping and going to a restaurant). }\end{array}$ \\
\hline \multirow[t]{2}{*}{ I2 } & Laurien & Mother & Girl (14) & 2 & $\begin{array}{l}\text { Two- } \\
\text { parent } \\
\text { family }\end{array}$ & $\begin{array}{c}\text { Migration } \\
\text { background }\end{array}$ & Nurse & High & $\begin{array}{l}\text { Middle } \\
\text { class }\end{array}$ & $\begin{array}{l}\text { Playing soccer }(*) \text {, youth organisation }(*) \text {, using social media, surfing } \\
\text { the internet, gaming, playing soccer with friends at home, doing } \\
\text { nothing, family visits. }\end{array}$ \\
\hline & Cristiano & Father & Boy (13) & & & & Technician & & & $\begin{array}{l}\text { Ballet }\left({ }^{*}\right) \text {, kickboxing }\left({ }^{*}\right) \text {, using social media, activities with friends } \\
\text { (e.g. going to the city and going to a movie theatre). }\end{array}$ \\
\hline I3 & An & Mother & Boy (18) & 2 & $\begin{array}{l}\text { Single } \\
\text { parent }\end{array}$ & $\begin{array}{c}\text { No } \\
\text { migration } \\
\text { background }\end{array}$ & Disabled $^{13}$ & Low & $\begin{array}{l}\text { Working } \\
\text { class }\end{array}$ & $\begin{array}{l}\text { Fitness, activities with friends (e.g. playing paintball, bowling, going } \\
\text { to a movie theatre), swimming, watching television, gaming, surfing } \\
\text { the internet, family activities (e.g. going to a movie theatre and doing } \\
\text { sports). }\end{array}$ \\
\hline I4 & Dirk & Father & Girl (17) & 2 & $\begin{array}{l}\text { Two- } \\
\text { parent } \\
\text { family }\end{array}$ & $\begin{array}{c}\text { No } \\
\text { migration } \\
\text { background }\end{array}$ & Teacher & High & $\begin{array}{l}\text { Middle } \\
\text { class }\end{array}$ & $\begin{array}{l}\text { Singing, playing piano and guitar, reading books, watching } \\
\text { television and movies, meeting friends at home, cooking and baking, } \\
\text { family activities (e.g. making city trips, travelling), family visits. }\end{array}$ \\
\hline $\mathrm{I} 5$ & Charlotte & Mother & Boy (14) & 2 & $\begin{array}{l}\text { Two- } \\
\text { parent }\end{array}$ & $\begin{array}{l}\text { No } \\
\text { migration }\end{array}$ & $\begin{array}{l}\text { Administrati } \\
\text { ve assistant }\end{array}$ & High & $\begin{array}{l}\text { Middle } \\
\text { class }\end{array}$ & $\begin{array}{l}\text { Hockey }\left(^{*}\right) \text {, horticulture, using social media (e.g. class chat), watching } \\
\text { television, family activities (e.g. making city trips and day trips), }\end{array}$ \\
\hline
\end{tabular}

${ }^{7}$ Biological as well as stepchildren (i.e. the biological children of one's partner).

${ }^{8}$ Biological as well as stepchildren.

${ }^{9}$ Families with a migration background are families where at least one of the parents or the grandparents had immigrated.

${ }^{10}$ The families' educational level is based on both parents' highest educational qualification. We call families' educational level as 'high' when at least one of the parents has a higher education and 'low' when none of the parents obtained a higher education.

11 The assigned social class position is based on the families' educational level.

${ }^{12}$ Activities with an asterisk $\left(^{*}\right)$ are organised leisure activities (i.e. adult-supervised, regular and rule-guided activities that take place in an institutional setting (Bennett, Lutz \& Jayaram, 2012)).

${ }^{13}$ Disabled refers to being unable to work for more than one year.

Q2020 Journal of Childhood, Education \& Society. This is an open access article under the CC BY- NC- ND license. (https://creativecommons.org/licenses/by/4.0/) 
Annelore VAN DER EECKEN, Bram SPRUYT \& Lieve BRADT

\begin{tabular}{|c|c|c|c|c|c|c|c|c|c|c|}
\hline & Michael & Father & & & $\begin{array}{c}\text { step- } \\
\text { family }^{14}\end{array}$ & background & Driver & & & $\begin{array}{l}\text { activities with relatives (e.g. bowling and playing snooker with } \\
\text { cousins), family visits. }\end{array}$ \\
\hline I6 & Rosalie & Mother & Girl (13) & 3 & $\begin{array}{l}\text { Single } \\
\text { parent }\end{array}$ & $\begin{array}{c}\text { No } \\
\text { migration } \\
\text { background }\end{array}$ & Sick leave & Low & $\begin{array}{l}\text { Working } \\
\text { class }\end{array}$ & $\begin{array}{l}\text { Youth organisation }(*) \text {, music school }\left({ }^{*}\right) \text {, watching television, using } \\
\text { social media, surfing the internet, family activities (e.g. shopping, } \\
\text { doing household tasks, watching television, helping with cooking } \\
\text { and cleaning, going to a restaurant, sitting on a terrace). }\end{array}$ \\
\hline I7 & Aida & Mother & Boy (12) & 3 & $\begin{array}{l}\text { Two- } \\
\text { parent } \\
\text { family }\end{array}$ & $\begin{array}{l}\text { Migration } \\
\text { background }\end{array}$ & $\begin{array}{l}\text { Cleaning } \\
\text { lady }\end{array}$ & Low & $\begin{array}{l}\text { Working } \\
\text { class }\end{array}$ & $\begin{array}{l}\text { Kick- and Thai boxing }\left({ }^{*}\right) \text {, running, riding a scooter, surfing the } \\
\text { internet, gaming, reading books, playing football in the park with } \\
\text { friends, phoning with family (e.g. on Skype), family activities (e.g. } \\
\text { going to a Fite Nite, going to a restaurant, praying, enjoying food at } \\
\text { home). }\end{array}$ \\
\hline \multirow[t]{2}{*}{ I8 } & \multirow[t]{2}{*}{ Eva } & \multirow[t]{2}{*}{ Mother } & Boy (15) & 3 & \multirow[t]{2}{*}{$\begin{array}{l}\text { Single } \\
\text { parent }\end{array}$} & \multirow[t]{2}{*}{$\begin{array}{c}\text { No } \\
\text { migration } \\
\text { background }\end{array}$} & \multirow[t]{2}{*}{ Teacher } & \multirow[t]{2}{*}{ High } & \multirow[t]{2}{*}{$\begin{array}{l}\text { Middle } \\
\text { class }\end{array}$} & $\begin{array}{l}\text { Playing soccer }\left({ }^{*}\right) \text {, going out, attending parties, meeting friends at } \\
\text { home, meeting friends in the city and in the park, etc., gaming, using } \\
\text { social media, family activities (watching television, going to the } \\
\text { seaside, watching movies, doing daytrips, etc.). }\end{array}$ \\
\hline & & & Boy (13) & & & & & & & $\begin{array}{l}\text { Gaming, riding a scooter, BMXing (in the skate park and in the city), } \\
\text { meeting friends in the city, in the park, using social media, surfing } \\
\text { the internet, family activities (watching television, going to the } \\
\text { seaside, watching movies, doing daytrips, etc.). }\end{array}$ \\
\hline I9 & Keicha & Mother & Girl (14) & 5 & $\begin{array}{l}\text { Two- } \\
\text { parent } \\
\text { step- } \\
\text { family }\end{array}$ & $\begin{array}{l}\text { Migration } \\
\text { background }\end{array}$ & Housewife & Low & $\begin{array}{l}\text { Working } \\
\text { class }\end{array}$ & $\begin{array}{l}\text { Watching television, reading strips, family activities (watching } \\
\text { television, sitting together in the living room, joining her younger } \\
\text { brother at his soccer training and games, making apple fritters, etc.), } \\
\text { family visits. }\end{array}$ \\
\hline I10 & Alice & Mother & Girl (16) & 2 & $\begin{array}{l}\text { Two- } \\
\text { parent } \\
\text { family }\end{array}$ & $\begin{array}{l}\text { No } \\
\text { migration } \\
\text { background }\end{array}$ & $\begin{array}{l}\text { (Routine) } \\
\text { clerical } \\
\text { worker }\end{array}$ & Low & $\begin{array}{l}\text { Working } \\
\text { class }\end{array}$ & $\begin{array}{l}\text { KSA }\left(^{*}\right) \text {, weekend work, babysitting, using social media, watching } \\
\text { television, going out, going to a pub, surfing the internet, activities } \\
\text { with relatives (parties, day trips, meeting cousins, etc.), family } \\
\text { activities (e.g. watching television). }\end{array}$ \\
\hline \multirow[t]{2}{*}{ I11 } & \multirow[t]{2}{*}{ Marie } & \multirow[t]{2}{*}{ Mother } & Boy (18) & 2 & \multirow[t]{2}{*}{$\begin{array}{l}\text { Two- } \\
\text { parent } \\
\text { family }\end{array}$} & \multirow[t]{2}{*}{$\begin{array}{c}\text { No } \\
\text { migration } \\
\text { background }\end{array}$} & \multirow[t]{2}{*}{ Teacher } & \multirow[t]{2}{*}{ High } & \multirow[t]{2}{*}{$\begin{array}{l}\text { Middle } \\
\text { class }\end{array}$} & $\begin{array}{l}\text { Floorball }(*) \text {, following Swedish lessons, visiting museums, drawing, } \\
\text { reading books, surfing the internet, going to a pub, watching } \\
\text { television, babysitting, using social media, gaming, meeting up with } \\
\text { girlfriend, doing chores, watching television. }\end{array}$ \\
\hline & & & Boy (16) & & & & & & & $\begin{array}{l}\text { Floorball }\left(^{*}\right) \text {, fitness, meeting friends in the city, watching television, } \\
\text { surfing the internet, using social media, gaming, babysitting, doing } \\
\text { chores, meeting up with girlfriend. }\end{array}$ \\
\hline I12 & Sien & Mother & Boy (13) & 1 & $\begin{array}{l}\text { Two- } \\
\text { parent } \\
\text { family }\end{array}$ & $\begin{array}{c}\text { No } \\
\text { migration } \\
\text { background }\end{array}$ & $\begin{array}{l}\text { (Routine) } \\
\text { clerical } \\
\text { worker }\end{array}$ & Low & $\begin{array}{l}\text { Working } \\
\text { class }\end{array}$ & $\begin{array}{l}\text { BMXing, skateboarding, riding a scooter and penny board in the } \\
\text { skate park and in the city, activities with friends at home (e.g. } \\
\text { gaming), using social media, meeting friends in the city and in the } \\
\text { park, watching television, watching movies, family visits, family } \\
\text { activities (e.g. watching television, shopping, going to a restaurant, }\end{array}$ \\
\hline
\end{tabular}

${ }^{14}$ Stepfamily refers to a family where the children of at least one of the parents are not biologically connected to the partner of the parent. 
Parents' role in adolescents' leisure time use: From goals...

\begin{tabular}{|c|c|c|c|c|c|c|c|c|c|c|}
\hline & & & & & & & & & & watching movies). \\
\hline I13 & Katrien & Mother & Girl (12) & 2 & $\begin{array}{l}\text { Two- } \\
\text { parent } \\
\text { family }\end{array}$ & $\begin{array}{c}\text { No } \\
\text { migration } \\
\text { background }\end{array}$ & $\begin{array}{l}\text { Finance } \\
\text { director }\end{array}$ & High & $\begin{array}{l}\text { Middle } \\
\text { class }\end{array}$ & $\begin{array}{l}\text { Dancing }\left({ }^{*}\right) \text {, youth organisation }\left({ }^{*}\right) \text {, watching television, watching } \\
\text { movies, using social media, being busy with her mobile phone, } \\
\text { activities with friends at home, surfing the internet, family visits, } \\
\text { family activities (watching television, city trips, etc.). }\end{array}$ \\
\hline I14 & Stijn & Father & Boy (14) & 3 & $\begin{array}{l}\text { Two- } \\
\text { parent } \\
\text { family }\end{array}$ & $\begin{array}{l}\text { No } \\
\text { migration } \\
\text { background }\end{array}$ & $\begin{array}{c}\text { Bank } \\
\text { manager }\end{array}$ & High & $\begin{array}{l}\text { Middle } \\
\text { class }\end{array}$ & $\begin{array}{l}\text { Playing soccer }(*) \text {, youth organisation }(*) \text {, gaming, playing soccer at } \\
\text { home with friends, watching YouTube videos, skateboarding and } \\
\text { BMXing in the skate park and in the city, watching television, } \\
\text { activities with cousins. }\end{array}$ \\
\hline I15 & $\begin{array}{c}\text { Diara } \\
\text { Denzell }\end{array}$ & $\begin{array}{l}\text { Mother } \\
\text { Father }\end{array}$ & Girl (13) & 5 & $\begin{array}{l}\text { Two- } \\
\text { parent } \\
\text { family }\end{array}$ & $\begin{array}{l}\text { Migration } \\
\text { background }\end{array}$ & $\begin{array}{l}\text { Housewife } \\
\text { Labourer }\end{array}$ & Low & $\begin{array}{l}\text { Working } \\
\text { class }\end{array}$ & $\begin{array}{l}\text { Watching television, reading books, babysitting, family activities (e.g. } \\
\text { watching television, going to church and praying). }\end{array}$ \\
\hline \multirow[t]{2}{*}{ I16 } & \multirow[t]{2}{*}{ Carol } & \multirow[t]{2}{*}{ Mother } & Boy (17) & 2 & \multirow[t]{2}{*}{$\begin{array}{l}\text { Single } \\
\text { parent }\end{array}$} & \multirow[t]{2}{*}{$\begin{array}{l}\text { No } \\
\text { migration } \\
\text { background }\end{array}$} & \multirow[t]{2}{*}{$\begin{array}{l}\text { Entrepreneu } \\
\mathrm{r}\end{array}$} & \multirow[t]{2}{*}{ High } & \multirow[t]{2}{*}{$\begin{array}{l}\text { Middle } \\
\text { class }\end{array}$} & $\begin{array}{l}\text { Cycling, gaming, playing football with friends at home, watching } \\
\text { football games in real life or on television, activities with friends (e.g. } \\
\text { going to a movie theatre, going to a show/performance), doing } \\
\text { nothing, letting the dog out, helping with household tasks (e.g. } \\
\text { cooking, mowing the lawn), weekend work, using social media, } \\
\text { being busy with his mobile phone, reading books, family activities } \\
\text { (e.g. watching television). }\end{array}$ \\
\hline & & & Girl (16) & & & & & & & $\begin{array}{l}\text { Going out, going to a pub, watching movies, meeting friends at } \\
\text { home, activities with friends (e.g. going to a movie theatre, going to a } \\
\text { show/performance), using social media, surfing the internet, being } \\
\text { busy with her mobile phone, reading books, doing nothing, helping } \\
\text { with household tasks (e.g. cooking, mowing the lawn), letting the } \\
\text { dog out, family activities (e.g. watching television, shopping). }\end{array}$ \\
\hline I17 & Sarah & Mother & Girl (18) & 1 & $\begin{array}{l}\text { Two- } \\
\text { parent } \\
\text { family }\end{array}$ & $\begin{array}{l}\text { No } \\
\text { migration } \\
\text { background }\end{array}$ & Sick leave & Low & $\begin{array}{l}\text { Working } \\
\text { class }\end{array}$ & $\begin{array}{l}\text { Meeting friends in the city, going to a pub, going out, meeting up } \\
\text { with boyfriend, watching television, helping out with household } \\
\text { tasks, surfing the internet, using social media, doing nothing, family } \\
\text { activities (e.g. shopping, going to a restaurant, watching television). }\end{array}$ \\
\hline \multirow[t]{2}{*}{ I18 } & Celien & Mother & Girl (16) & \multirow[t]{2}{*}{2} & \multirow[t]{2}{*}{$\begin{array}{l}\text { Two- } \\
\text { parent } \\
\text { family }\end{array}$} & \multirow[t]{2}{*}{$\begin{array}{c}\text { No } \\
\text { migration } \\
\text { background }\end{array}$} & \multirow{2}{*}{$\begin{array}{l}\text { (Higher) } \\
\text { clerical } \\
\text { employee } \\
\text { (Higher) } \\
\text { clerical } \\
\text { employee }\end{array}$} & \multirow[t]{2}{*}{ High } & \multirow[t]{2}{*}{$\begin{array}{l}\text { Middle } \\
\text { class }\end{array}$} & $\begin{array}{l}\text { Athletics }\left({ }^{*}\right) \text {, youth organisation }\left({ }^{*}\right) \text {, hockey }\left({ }^{*}\right) \text {, going out, meeting up } \\
\text { with boyfriend (at home), going to a pub, using social media, } \\
\text { watching YouTube videos. }\end{array}$ \\
\hline & Nathan & Father & Boy (14) & & & & & & & $\begin{array}{l}\text { Playing Soccer }(*) \text {, youth organisation }(*) \text {, gaming, watching } \\
\text { YouTube videos, watching television, family activities (e.g. watching } \\
\text { television). }\end{array}$ \\
\hline \multirow[t]{2}{*}{ I19 } & \multirow[t]{2}{*}{ Karel } & \multirow[t]{2}{*}{ Father } & Girl (17) & 3 & \multirow[t]{2}{*}{$\begin{array}{l}\text { Two- } \\
\text { parent } \\
\text { family }\end{array}$} & \multirow[t]{2}{*}{$\begin{array}{c}\text { No } \\
\text { migration } \\
\text { background }\end{array}$} & \multirow[t]{2}{*}{$\begin{array}{l}\text { Computer } \\
\text { scientist }\end{array}$} & \multirow[t]{2}{*}{ High } & \multirow[t]{2}{*}{$\begin{array}{l}\text { Middle } \\
\text { class }\end{array}$} & $\begin{array}{l}\text { Fitness, meeting friends at home, going to a pub, drawing, tinkering, } \\
\text { being on her own in her room, doing chores, surfing the internet, } \\
\text { using social media, family activities (e.g. city trips), family visits. }\end{array}$ \\
\hline & & & Boy (15) & & & & & & & $\begin{array}{l}\text { Playing soccer }(*) \text {, youth organisation }(*) \text {, gaming, watching football } \\
\text { games in real life or on television, doing chores, using social media, } \\
\text { family activities (e.g. city trips), family visits. }\end{array}$ \\
\hline
\end{tabular}


Annelore VAN DER EECKEN, Bram SPRUYT \& Lieve BRADT

\begin{tabular}{|c|c|c|c|c|c|c|c|c|c|c|}
\hline $\mathrm{I} 20$ & Lore & Mother & Boy (17) & 1 & $\begin{array}{l}\text { Single } \\
\text { parent }\end{array}$ & $\begin{array}{c}\text { No } \\
\text { migration } \\
\text { background }\end{array}$ & Advisor & High & $\begin{array}{c}\text { Middle } \\
\text { class }\end{array}$ & $\begin{array}{l}\text { Playing soccer }\left(^{*}\right) \text {, watching football games in real life or on } \\
\text { television, watching television, gaming, using social media, going } \\
\text { out, surfing the internet, attending a stand-up comedian show, } \\
\text { cooking, family visits, family activities (e.g. city trips, voluntary } \\
\text { work). }\end{array}$ \\
\hline \multirow[t]{2}{*}{$\mathrm{I} 21$} & \multirow[t]{2}{*}{ Peter } & \multirow[t]{2}{*}{ Father } & Girl (15) & \multirow[t]{2}{*}{4} & \multirow{2}{*}{$\begin{array}{l}\text { Two- } \\
\text { parent } \\
\text { step- } \\
\text { family }\end{array}$} & \multirow[t]{2}{*}{$\begin{array}{c}\text { No } \\
\text { migration } \\
\text { background }\end{array}$} & \multirow[t]{2}{*}{ Disabled } & \multirow[t]{2}{*}{ Low } & \multirow[t]{2}{*}{$\begin{array}{c}\text { Working } \\
\text { class }\end{array}$} & $\begin{array}{l}\text { Meeting friends in the city, watching television, using social media, } \\
\text { going out, doing someone's hair, family activities (e.g. shopping with } \\
\text { her stepmother, going to a restaurant). }\end{array}$ \\
\hline & & & Boy (15) & & & & & & & $\begin{array}{l}\text { Activities with friends (going to a movie theatre, going to the city), } \\
\text { watching television, weekend work, gaming, watching YouTube } \\
\text { videos, playing with the dog, family visits, family activities (e.g. } \\
\text { going to a restaurant). }\end{array}$ \\
\hline $\mathrm{I} 22$ & Mira & Mother & Girl (13) & 4 & $\begin{array}{l}\text { Two- } \\
\text { parent } \\
\text { step- } \\
\text { family }\end{array}$ & $\begin{array}{c}\text { No } \\
\text { migration } \\
\text { background }\end{array}$ & $\begin{array}{l}\text { Housewife } \\
\text { Labourer }\end{array}$ & Low & $\begin{array}{c}\text { Working } \\
\text { class }\end{array}$ & $\begin{array}{l}\text { Watching (creative) YouTube videos, being busy with make-up, } \\
\text { going to the city with friends, meeting friends at home, watching } \\
\text { television, listening to music, being busy with her mobile phone, } \\
\text { surfing the internet, using social media, doing nothing, helping out a } \\
\text { little bit around the house, family activities (e.g. resting together, } \\
\text { going to an amusement park). }\end{array}$ \\
\hline \multirow[t]{2}{*}{$\mathrm{I} 23$} & \multirow[t]{2}{*}{ Lea } & \multirow[t]{2}{*}{ Mother } & Girl (18) & 3 & \multirow[t]{2}{*}{$\begin{array}{l}\text { Two- } \\
\text { parent } \\
\text { family }\end{array}$} & \multirow[t]{2}{*}{$\begin{array}{c}\text { No } \\
\text { migration } \\
\text { background }\end{array}$} & \multirow[t]{2}{*}{ Teacher } & \multirow[t]{2}{*}{ High } & \multirow[t]{2}{*}{$\begin{array}{c}\text { Middle } \\
\text { class }\end{array}$} & $\begin{array}{l}\text { Harmony }(*) \text {, music school }(*) \text {, youth organisation }\left(^{*}\right) \text {, youth } \\
\text { orchestra }(*) \text { symphony orchestra }(*) \text {, reading books, tinkering, } \\
\text { sewing, family activities (e.g. going out for an ice cream, going to } \\
\text { museums, voluntary work). }\end{array}$ \\
\hline & & & Boy (14) & & & & & & & $\begin{array}{l}\text { Youth organisation }\left({ }^{*}\right) \text {, athletics }\left({ }^{*}\right) \text {, hockey }\left({ }^{*}\right) \text {, music school }\left({ }^{*}\right) \text {, } \\
\text { harmony }\left({ }^{*}\right) \text {, using social media, watching television programmes } \\
\text { and YouTube videos, reading books, learning to cook, meeting } \\
\text { friends at home, family activities (e.g. going out for an ice cream, } \\
\text { going to museums, voluntary work). }\end{array}$ \\
\hline \multirow[t]{3}{*}{$\mathrm{I} 24$} & \multirow[t]{3}{*}{ Emma } & \multirow[t]{3}{*}{ Mother } & Girl (15) & 5 & \multirow[t]{3}{*}{$\begin{array}{l}\text { Two- } \\
\text { parent } \\
\text { step- } \\
\text { family }\end{array}$} & \multirow[t]{3}{*}{$\begin{array}{c}\text { No } \\
\text { migration } \\
\text { background }\end{array}$} & \multirow[t]{3}{*}{ Teacher } & \multirow[t]{3}{*}{ High } & \multirow[t]{3}{*}{$\begin{array}{c}\text { Middle } \\
\text { class }\end{array}$} & $\begin{array}{l}\text { Music school }\left({ }^{*}\right) \text {, drawing academy }\left(^{*}\right) \text {, watching television, reading } \\
\text { books, going to the opera, doing chores (e.g. emptying the } \\
\text { dishwasher), family activities (e.g. going to a movie theatre, classical } \\
\text { concert, cultural centre). }\end{array}$ \\
\hline & & & Boy (14) & & & & & & & $\begin{array}{l}\text { Hockey }\left(^{*}\right) \text {, youth organisation }\left(^{*}\right) \text {, watching television, reading } \\
\text { books, using social media (e.g. class chat), listening to music, doing } \\
\text { chores (e.g. emptying the dishwasher), family activities (e.g. going to } \\
\text { a movie theatre, classical concert, cultural centre). }\end{array}$ \\
\hline & & & Girl (12) & & & & & & & $\begin{array}{l}\text { Music school }(*) \text {, using social media, watching television, listening to } \\
\text { music, doing chores (e.g. emptying the dishwasher), family activities } \\
\text { (e.g. going to a movie theatre, classical concert, cultural centre). }\end{array}$ \\
\hline $\mathrm{I} 25$ & Malika & Mother & Boy (18) & 4 & $\begin{array}{l}\text { Two- } \\
\text { parent } \\
\text { family }\end{array}$ & $\begin{array}{c}\text { Migration } \\
\text { background }\end{array}$ & Housewife & Low & $\begin{array}{c}\text { Working } \\
\text { class }\end{array}$ & $\begin{array}{l}\text { Fitness, activities with friends (e.g. going to the city, swimming), } \\
\text { weekend work, gaming, watching television, using social media, } \\
\text { watching YouTube videos, praying, going to a mosque, family visits. }\end{array}$ \\
\hline
\end{tabular}


Girl (16)

Boy (13)

\begin{tabular}{|c|c|c|c|c|c|c|c|c|c|}
\hline $\mathrm{I} 26$ & Elisa & Mother & Girl (14) & 3 & $\begin{array}{l}\text { Single } \\
\text { parent }\end{array}$ & $\begin{array}{c}\text { No } \\
\text { migration } \\
\text { background }\end{array}$ & $\begin{array}{c}\text { Cleaning } \\
\text { lady }\end{array}$ & Low & $\begin{array}{c}\text { Working } \\
\text { class }\end{array}$ \\
\hline
\end{tabular}

Watching television, using social media, watching YouTube videos, family activities (e.g. shopping), household tasks (e.g. doing the dishes), activities with friends (e.g. shopping, eating a snack) praying, going to mosque, family visits.

Watching television, gaming, praying, going to a mosque, family visits.

Youth organisation $\left(^{*}\right)$, using social media, surfing the internet, watching television, activities with friends (going to the fair, the city, etc.), meeting friends at home, meeting up with boyfriend, family activities (e.g. shopping, going to a fair, an amusement park, the seaside).

Youth organisation $\left({ }^{*}\right)$, using social media, watching television, surfing the internet, family activities (e.g. shopping, going to a fair, an amusement park, the seaside).

\begin{tabular}{|c|c|c|c|c|c|c|c|c|c|}
\hline I27 & Karen & Mother & Girl (14) & 3 & $\begin{array}{l}\text { Single } \\
\text { parent }\end{array}$ & $\begin{array}{c}\text { No } \\
\text { migration } \\
\text { background }\end{array}$ & $\begin{array}{l}\text { Cleaning } \\
\text { lady }\end{array}$ & Low & $\begin{array}{c}\text { Working } \\
\text { class }\end{array}$ \\
\hline \multirow[t]{2}{*}{$\mathrm{I} 28$} & Ines & Mother & Boy (18) & 2 & $\begin{array}{l}\text { Two- } \\
\text { parent } \\
\text { family }\end{array}$ & $\begin{array}{c}\text { No } \\
\text { migration } \\
\text { background }\end{array}$ & $\begin{array}{c}\text { Patient care } \\
\text { assistant }\end{array}$ & Low & $\begin{array}{c}\text { Working } \\
\text { class }\end{array}$ \\
\hline & & & Girl (13) & & & & & & \\
\hline
\end{tabular}

\begin{tabular}{|c|c|c|c|c|c|c|c|c|c|}
\hline $\mathrm{I} 29$ & Martin & Father & Boy (16) & 2 & $\begin{array}{l}\text { Two- } \\
\text { parent } \\
\text { family }\end{array}$ & $\begin{array}{c}\text { No } \\
\text { migration } \\
\text { background }\end{array}$ & Sick leave & Low & $\begin{array}{c}\text { Working } \\
\text { class }\end{array}$ \\
\hline
\end{tabular}

Boy (12)

\begin{tabular}{cccccccccc}
\hline I30 & Tine & Mother & Girl (13) & 1 & $\begin{array}{c}\text { Two- } \\
\text { parent } \\
\text { family }\end{array}$ & $\begin{array}{c}\text { No } \\
\text { migration } \\
\text { background }\end{array}$ & $\begin{array}{c}\text { (Higher) } \\
\text { clerical } \\
\text { employee }\end{array}$ & $\begin{array}{c}\text { High } \\
\text { Middle } \\
\text { class }\end{array}$ \\
\hline I31 & Mona & Mother & Girl (17) & 2 & $\begin{array}{c}\text { Single } \\
\text { parent }\end{array}$ & $\begin{array}{c}\text { No } \\
\text { migration } \\
\text { background }\end{array}$ & Teacher & High & $\begin{array}{c}\text { Middle } \\
\text { class }\end{array}$ \\
\end{tabular}

Using social media, meeting friends in the city and in the park watching television, family activities (e.g. shopping, going to the seaside), family visits, listening to music, doing nothing.

Watching television, activities with friends (e.g. going to (birthday) parties, a movie theatre, holiday parks), gaming, surfing the internet, using social media, weekend work.

Gymnastics $\left(^{*}\right)$, activities with friends (e.g. Halloween tours, birthday parties, shopping, going to a movie theatre), reading books, watching (creative) YouTube videos, watching series, using social media, tinkering.

Playing soccer $\left(^{*}\right)$, watching television, meeting up with girlfriend (at home), using social media, family activities (e.g. watching television, visiting amusement parks, doing nothing, having dinner together), family visits.

Playing soccer $(*)$, watching television, using social media, playing pool and snooker with father, family activities (e.g. watching together), family visits.

Water ballet $\left(^{*}\right)$, activities with friends (e.g. going to the city, eating an ice cream), meeting friends at home, family activities (e.g. going to the movie theatre, doing day trips), surfing the internet.

Ballet $\left(^{*}\right)$, youth organisation $(*)$, guitar lessons (private), weekend work, meeting up with boyfriend (e.g. going to a movie theatre), meeting friends at home (e.g. cooking together), going out, watching television, using social media, being busy with her mobile phone, watching YouTube videos, doing chores (e.g. cleaning the table), family activities (e.g. going to a restaurant, travelling together), television, visiting amusement parks, doing nothing, having dinner 
Annelore VAN DER EECKEN, Bram SPRUYT \& Lieve BRADT

\begin{tabular}{|c|c|c|c|c|c|c|c|c|c|c|}
\hline & & & & & & & & & & family visits. \\
\hline & & & Boy (14) & & & & & & & $\begin{array}{l}\text { Playing soccer }\left({ }^{*}\right) \text {, youth organisation }\left({ }^{*}\right) \text {, gaming, watching } \\
\text { television, using social media, doing chores (e.g. cleaning the table), } \\
\text { family activities (e.g. going to a restaurant, travelling together), } \\
\text { family visits. }\end{array}$ \\
\hline \multirow[t]{3}{*}{ I32 } & \multirow[t]{3}{*}{ Gertie } & \multirow[t]{3}{*}{ Mother } & Boy (18) & 6 & \multirow[t]{3}{*}{$\begin{array}{l}\text { Two- } \\
\text { parent } \\
\text { step- } \\
\text { family }\end{array}$} & \multirow[t]{3}{*}{$\begin{array}{l}\text { No } \\
\text { migration } \\
\text { background }\end{array}$} & \multirow[t]{3}{*}{ Disabled } & \multirow[t]{3}{*}{ Low } & \multirow[t]{3}{*}{$\begin{array}{c}\text { Working } \\
\text { class }\end{array}$} & $\begin{array}{l}\text { Gaming, meeting up with friends in the district, going to a pub, } \\
\text { weekend work, being busy with his mobile phone, using social } \\
\text { media, doing chores (e.g. doing the dishes), family activities (e.g. } \\
\text { swimming, watching television, walking, going to an amusement } \\
\text { park). }\end{array}$ \\
\hline & & & Boy (13) & & & & & & & $\begin{array}{l}\text { Gaming, meeting up with friends in the district, using social media, } \\
\text { watching television, doing chores (e.g. doing the dishes), family } \\
\text { activities (e.g. swimming, walking, going to an amusement park). }\end{array}$ \\
\hline & & & Boy (12) & & & & & & & $\begin{array}{l}\text { Playing soccer }\left({ }^{*}\right) \text {, meeting up with friends in the district, gaming, } \\
\text { using social media, watching television, doing chores (e.g. doing the } \\
\text { dishes), family activities (e.g. swimming, walking, going to an } \\
\text { amusement park). }\end{array}$ \\
\hline
\end{tabular}

